\title{
Peran dan Fungsi Penyiaran Menurut Undang-Undang Penyiaran Tahun 2002 dan Perkembangannya
}

\author{
Syaifudin Zuhri ${ }^{1}$ \\ ${ }^{1}$ Fakultas Dakwah dan Komunikasi, Universitas Islam Negeri Sunan Ampel Surabaya, Indonesia
}

Kata kunci:

Peran;

Fungsi;

Penyiaran.

\begin{abstract}
Keywords:
Roles;

Functions;

Broadcasting

Abstract: The broadcasting reform in 2002 has not yet been able to produce a broadcasting system that is democratic, educational and in accordance with the wishes and expectations of the community. The purpose of this writing is to examine the role and function of broadcasting according to the 2002 broadcasting law and its current development. This research is descriptiveanalytical with the approach in this study is qualitative. The results of this study show that the broadcast media performs its duties and functions as regulated by the Broadcasting Law, therefore all broadcast media including practitioners must comply with the laws and ethics of broadcasting. The role and function of radio and television broadcasting media is increasing in line with the development of the times, especially the development of society and the country. So that it can be concluded by the existence of a clean government, a real democratic state and the enforcement of the values of justice in the community will not be realized if the role and function of broadcasting is not maximized.
\end{abstract}

\section{ABSTRACT}

Abstrak: Reformasi penyiaran tahun 2002 sampai saat ini belum mampu melahirkan sistem penyiaran yang demokratis, mendidik dan sesuai dengan kehendak dan harapan masyarakat. Tujuan dari penulisan ini yaitu untuk mengkaji mengenai peran dan fungsi penyiaran menurut undang-undang penyiaran tahun 2002 dan perkembangannya saat ini. Penelitian ini bersifat deskriptik- analitik dengan Pendekatan dalam penelitian ini adalah kualitatif. Hasil dari penelitian ini menujukkan media penyiaran menjalankan tugas dan fungsinya sebagaimana yang telah diatur oleh UU Penyiaran, karena itu semua media penyiaran termasuk praktisinya harus taat dengan hukum dan etika penyiaran. Peran dan fungsi media penyiaran Radio dan Televisi saat ini semakin besar seiring dengan perkembangan zaman khususnya perkembangan masyarakat dan negara. Sehingga dapat disimpulkan dengan adanya Pemerintahan yang bersih (clean government), negara demokratis yang sesungguhnya serta penegakan nilai-nilai keadilan di masyarakat tidak akan terwujud apabila peran dan fungsi penyiaran tidak dimaksimalkan.

Alamat Korespondensi:

E-mail: zuhri656@gmail.com (Zuhri)

\section{Pendahuluan}

Di masa rezim lama regulasi yang berkenaan dengan penyiaran televisi dan radio diatur melalui Surat Keputusan Menteri Penerangan Nomor 20/SK/M/1961, namun regulasi yang wujud dalam bentuk Undang-undang, yaitu Undangundang penyiaran baru hadir dipenghujung kekuasaan Orde Baru (Orba) dan pada masa awal reformasi yaitu UU No. 24 Tahun 1997 dan UU No. 32 Tahun 2002. Manfaat luar biasa yang dapat diperoleh dari penyiaran digital, Indonesia menghadapi beberapa tantangan yang timbul dalam peralihan ke penyiaran digital (Gultom, 2015). Di sisi regulasi, UU Penyiaran saat ini belum mengatur penyiaran digital secara spesifik. Perlu segera disahkan UU Penyiaran yang baru agar dapat mengakomodasi regulasi terkait penyiaran digital. Permasalahan hukum terkait regulasi penyiaran digital berdampak tenggat waktu peralihan dari analog ke penyiaran televisi digital tahun 2018 yang tidak dapat dipenuhi. Di sisi konsumen, untuk dapat

$\begin{array}{ll}\text { History: } & \\ \text { Received } & \text { : 02 Maret } 2021 \\ \text { Revised } & : 06 \text { Maret } 2021 \\ \text { Accepted } & : 6 \text { Juni } 2021 \\ \text { Published } & : 25 \text { Juli } 2021\end{array}$

Publisher: Undiksha Press

Licensed: This work is licensed under a Creative Commons Attribution 3.0 License

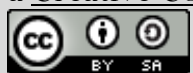


mendapatkan layanan televisi digital di televisi analog mereka diwajibkan untuk memiliki dekoder. Untuk jadi perhatian pemerintah terkait penyediaan dekoder agar mudah diperoleh.

Namun reformasi penyiaran tahun 2002 sampai saat ini belum mampu melahirkan sistem penyiaran yang demokratis, mendidik dan sesuai dengan kehendak dan harapan masyarakat. UU Penyiaran mengatur bahwa Negara menguasai spektrum frekuensi yang digunakan untuk penyelenggaraan penyiaran guna sebesar-besarnya kemakmuran rakyat (Kridasaksana et al., 2017). UU Penyiaran menegaskan bahwa frekuensi penyiaran merupakan milik publik dan pemerintah mempunyai kewenangan untuk mengatur penggunaannya. UU Penyiaran juga mengatur bahwa isi siaran wajib dijaga netralitasnya dan tidak boleh mengutamakan kepentingan golongan tertentu. Jadi jelas bahwa sudah seharusnya sesuatu yang secara kemanfaatan diselenggarakan untuk kepentingan rakyat banyak, dikembalikan fungsinya untuk kepentingan rakyat, bukan kepentingan golongan tertentu dalam hal ini pemilik modal (Denico Doly, 2021).

Strategi dan rekomendasi yang dapat dilakukan pemerintah untuk menghadirkan penyiaran digital di daerah perbatasan (Yuniarti \& Kusumawardani, 2018). Regulasi mengenai penyiaran diatur berdasarkan Undang-Undang No. 32 Tahun 2002 digunakan untuk melakukan pengawasan dan sekaligus dipakai sebagai pedoman dalam memproduksi dan menayangkan isi siaran televise (Stirman, 2016). Selain itu, Lembaga Penyiaran selaku penyelenggara siaran televisi memiliki tanggung jawab kepada masyarakat dalam menayangkan isi siaran televisi yang diatur di dalam UndangUndang Penyiaran, Pedoman Perilaku Penyiaran, dan Standar Program Siaran. Dalam kontek penyiaran nasional dengan payung hukum UU 32/ 2002 telah menjadi dasar yang kuat, apa lagi kemudian pemerintah menerbitkan sejumlah paket Peraturan Pemerintah (PP) tentang penyiaran, yaitu PP 11/ 2005, PP 12/ 2005, PP 50/ 2005; PP 51/ 2005 dan PP 52/ 2005. Adapun tujuan dari penelitian ini yaitu untuk menganalisis peran dan fungsi penyiaran menurut undang-undang penyiaran tahun 2002 dan perkembangannya

\section{Metode}

Penelitian ini bersifat deskriptik- analitik, yaitu memaparkan secara lengkap bagaimana peran dan fungsi penyiaran menurut undang-undang penyiaran tahun 2002 dan perkembangannya, dimana untuk selanjutnya dianalisa dengan menggunakan pendekatan yuridis empiris. Penelitian seperti ini juga sering disebut sebagai penelitian kepustakaan, yaitu prosedur untuk mengumpulkan data yang bersumber dari literatur atau bahan literatur, perundang-undangan terkait, tulisan atau penelitian hukum. Pendekatan dalam penelitian ini adalah kualitatif dengan berorientasi pada pengembangan narasi dan / atau deskripsi tekstual dari fenomena yang diteliti. Sumber data utama penelitian ini adalah studi literatur, yaitu dengan mengamati, mempelajari, membaca materi hukum dan keputusan serta dokumen yang terkait dengan penelitian ini

\section{Hasil dan Pembahasan}

\section{Hasil Penelitian}

Sesuai dengan UU 32/ 2002, lembaga penyiaran terbagi dalam 4 jenis yaitu: Lembaga Penyiaran Publik; Lembaga Penyiaran Swasta; Lembaga Penyiaran Komunitas; dan Lembaga Penyiaran Berlangganan Ke empat jenis lembaga penyiaran tersebut memiliki karakteristik yang berbeda-beda, sehingga masing- masing memiliki spesifikasi baik bentuk lembaga, manajemen maupun karakter yuridis formalnya. Terdapat lima jenis lembaga penyiaran yang dirangkum melalui tabel 1.

Peran, tujuan dan fungsi penyiaran, media penyiaran merupakan salah satu media yang sangat berpengaruh pada masyarakat Indonesia (Denico Doly, 2021). Pengaruh besar yang diberikan media penyiaran dapat memberikan dampak negatif ataupun dampak positif bagi masyarakat, oleh karena itu perlu ada aturan terkait dengan penyelenggaraan penyiaran yang didalamnya mengatur tentang lembaga penyiaran, isi siaran, sistem penyiaran, dan lain-lain. Pengaturan mengenai penyelenggaraan penyiaran dimaksudkan untuk memberikan kepastian hukum bagi masyarakat 
untuk mendapatkan informasi dan berita yang benar juga hiburan yang mendidik bagi masyarakat (Denico Doly, 2021). Seperti telah disebutkan, bahwa UndangUndang Nomor 32 Tahun 2002 tentang Penyiaran dibentuk atas dasar semangat reformasi yang sudah ada pada saat itu. Adapun perubahan mendasar yang terjadi antara Undang-Undang Nomor 24 Tahun 1997 Tentang Penyiaran dengan Undang-Undang Nomor 32 Tahun 2002 tentang Penyiaran dapat dilihat dari beberapa perubahan.

Tabel 1. Jenis Lembaga PenyiaranBerdasarkan UU 32/ 2002

\begin{tabular}{|c|c|c|c|c|}
\hline No & $\begin{array}{c}\text { Jenis Lembaga } \\
\text { Penyiaran }\end{array}$ & Payung Hukum & Karakter Yuridis & $\begin{array}{l}\text { Model Program \& } \\
\text { Sumber Anggaran }\end{array}$ \\
\hline 1. & $\begin{array}{l}\text { Lembaga Penyiaran } \\
\text { Publik (LPP) } \\
\text { RRI, TVRI }\end{array}$ & $\begin{array}{ll}\checkmark & \text { PP No. 11/ } 2005 \\
\checkmark & \text { PP No.12 / } 2005 \\
& \text { (khusus RRI) }\end{array}$ & $\begin{array}{ll}\checkmark & \text { Publik, } \\
\checkmark & \text { Pemerintah, } \\
\checkmark & \text { Organ: Dewan } \\
& \text { Pengawas dan. } \\
\text { Dewan Direksi } \\
\checkmark \quad \text { Bersifat Independen, } \\
\quad \text { netral } \\
\checkmark \text { Non Komersil }\end{array}$ & $\begin{aligned} \checkmark & \text { Umum } \\
& \text { (informasi, } \\
& \text { hiburan, Iklan) } \\
\checkmark & \text { APBN }\end{aligned}$ \\
\hline 2. & $\begin{array}{l}\text { Lembaga Penyiaran } \\
\text { Publik Lokal (LPPL) } \\
\text { Radio dan Televisi }\end{array}$ & $\begin{array}{ll}\checkmark & \text { PP No. 11/ } 2005 \\
\checkmark & \text { Perda } \\
& \text { (Peraturan } \\
& \text { Daerah) }\end{array}$ & $\begin{array}{ll}\checkmark & \text { Publik Lokal } \\
\checkmark & \text { Pemerintah Daerah } \\
\checkmark & \text { Organ: Dewan } \\
& \text { Pengawas. } \\
\text { Dewan Direksi } \\
\checkmark \text { Independen, netral } \\
\checkmark & \text { Non Komersil }\end{array}$ & $\begin{aligned} \checkmark & \text { Umum } \\
& \text { (informasi, } \\
& \text { hiburan, Iklan) } \\
\checkmark & \text { APBD Prop, } \\
& \text { Kab.Kota } \\
\checkmark & \text { Pendapatan } \\
& \text { iklan }\end{aligned}$ \\
\hline 3 & $\begin{array}{l}\text { Lembaga Penyiaran } \\
\text { Swasta (LPS) Radio } \\
\text { dan Televisi }\end{array}$ & $\begin{aligned} \checkmark & \text { PP No.50/ } 2005 \\
\checkmark & \text { Keputusan } \\
& \text { Menkominfo } \\
\checkmark & \text { Peraturan } \\
& \text { Menkominfo }\end{aligned}$ & $\begin{aligned} & \checkmark \text { Swasta Komersil } \\
& \checkmark \text { Berbadan Hukum PT } \\
& \text { (Perseroan Terbatas) } \\
& \checkmark \text { Siarannya bisa free to } \\
& \text { air melalui sistem } \\
& \text { terestrial. } \\
& \checkmark \text { Dapat berjaringan } \\
& \text { dengan LPS-LPS } \\
& \text { anggotanya di } \\
& \text { berbagai daerah. } \\
& \checkmark \text { Profit oriented, } \\
& \text { pengelolaan harus } \\
& \text { profesional }\end{aligned}$ & $\begin{aligned} \checkmark & \text { Umum } \\
& \text { (informasi, } \\
& \text { hiburan, Iklan) } \\
\checkmark & \text { Iklan }\end{aligned}$ \\
\hline 4. & $\begin{array}{l}\text { Lembaga Penyiaran } \\
\text { Komunitas (LPK) } \\
\text { Radio dan Televisi }\end{array}$ & $\begin{aligned} \checkmark & \text { PP No.51/ } 2005 \\
\checkmark & \text { Keputusan } \\
& \text { Menkominfo } \\
\checkmark & \text { Peraturan } \\
& \text { Menkominfo }\end{aligned}$ & $\begin{aligned} & \checkmark \text { Swasta Komunitas } \\
& \checkmark \text { Hanya untuk } \\
& \text { kepentingan } \\
& \text { komunitas dengan } \\
& \text { prinsip “dari, oleh } \\
& \text { untuk komunitas-nya } \\
& \checkmark \text { Berbadan Hukum } \\
& \text { Perkumpunan atau } \\
& \text { Koperasi } \\
& \checkmark \text { Berdaya pancar } \\
& \text { rendah } \\
& \checkmark \text { Jangkauan siar dan } \\
& \text { layanan siar sangat } \\
& \text { dibatasi }\end{aligned}$ & $\begin{aligned} \checkmark & \text { Umum } \\
& \text { (informasi, } \\
& \text { hiburan, Iklan) } \\
\checkmark & \text { Iklan Layanan } \\
& \text { Masyarakat }\end{aligned}$ \\
\hline
\end{tabular}




\begin{tabular}{|c|c|c|c|c|}
\hline No & $\begin{array}{c}\text { Jenis Lembaga } \\
\text { Penyiaran }\end{array}$ & Payung Hukum & Karakter Yuridis & $\begin{array}{l}\text { Model Program \& } \\
\text { Sumber Anggaran }\end{array}$ \\
\hline 5 & $\begin{array}{l}\text { Lembaga Penyiaran } \\
\text { Berlangganan (LPB) } \\
\text { Televisi }\end{array}$ & $\begin{array}{ll}\checkmark & \text { PP No.51/2005 } \\
\checkmark & \text { Keputusan } \\
& \text { Menkominfo } \\
\checkmark & \text { Peraturan } \\
& \text { Menkominfo }\end{array}$ & $\begin{array}{ll}\checkmark & \text { Non Komersil } \\
\checkmark & \text { Non Partisan } \\
\checkmark & \text { Swasta Komersil } \\
\checkmark & \text { Berbadan Hukum PT } \\
\checkmark & \text { sistem siarannya } \\
& \text { menggunakan satelit, } \\
& \text { kabel atau terestrial, } \\
& \text { menawarkan variasi } \\
& \text { program siaran yang } \\
& \text { dapat dipilih } \\
\text { pelanggannya. }\end{array}$ & $\begin{array}{ll}\checkmark & \text { Umum } \\
& \text { (informasi, } \\
& \text { hiburan, Iklan) } \\
\checkmark & \text { Iklan Layanan } \\
& \text { Masyarakat } \\
\checkmark & \text { Iuran } \\
& \text { Pelanggan }\end{array}$ \\
\hline
\end{tabular}

Perubahan yang pertama yaitu dibentuknya badan regulator penyiaran yaitu KPI, kedua, yaitu sistem siaran berjaringan, perubahan ketiga, yaitu dijaminnya LPK, keempat, LPP, dan kelima pembatasan LPS. Berdasarkan apa yang dikemukakan sebelumnya mengenai perubahan substansi yang dilakukan pada Undang-Undang Nomor 24 Tahun 1997 tentang Penyiaran menjadi UndangUndang Nomor 32 Tahun 2002 tentang Penyiaran, maka dapat dikemukakan beberapa permasalahan dalam Undang-Undang Nomor 32 Tahun 2002 tentang Penyiaran sehingga undangundang tersebut belum dapat dijalankan secara maksimal. Hal ini juga kemudian yang menjadikan UU Penyiaran mempunyai kelembahan substansi. UU Penyiaran merupakan undang-undang yang melahirkan sebuah lembaga independen yang mengatur mengenai hal-hal penyiaran yaitu Komisi Penyiaran Indonesia. Pengaturan mengenai KPI diatur dalam BAB III bagian Kedua Pasal 7 sampai 12 UU Penyiaran. Aturan mengenai KPI menunjukkan bahwa penyiaran tidak diatur oleh pemerintah lagi, akan tetapi oleh lembaga independen yang dibentuk berdasarkan UU Penyiaran yaitu KPI. Oleh karena itu, segala sesuatu yang berkaitan dengan penyelenggaraan penyiaran tidak hanya melibatkan unsur Pemerintah saja, akan tetapi juga melibatkan KPI. KPI sebagai lembaga negara mempunyai tugas dan kewajiban yang telah diatur dalam UU Penyiaran (Murni, 2017). Adapun tugas dan kewajiban ini terkait dengan penyelenggaraan penyiaran, khususnya terkait dengan isi siaran dan izin penyelenggaraan penyiaran.

Sistem siaran jaringan diatur dalam UU Penyiaran, dimana LPS Pusat maupun LPP Pusat wajib melakukan siaran jaringan dengan lembaga penyiaran yang berada di daerah. Saat ini ketentuan mengenai sistem siaran jaringan ini belum dilaksanakan (Ahmad Budiman, 2016). Hal ini dapat dilihat dari banyaknya LPS yang melakukan siaran secara nasional. Permasalahan sistem siaran jaringan ini juga berkaitan dengan isi siaran. Hal ini dapat dilihat dari frekuensi yang dapat digunakan oleh LPK (Ahmad Budiman, 2016). Keberadaan LPK merupakan salah satu pengaturan dalam UU Penyiaran yang menunjukkan adanya demokrasi dalam pembentukan lembaga penyiaran. LPK merupakan lembaga penyiaran yang dapat dibentuk oleh semua orang yang berorientasi kepada kebutuhan masyarakat. LPP saat ini dilakukan oleh Televisi Republik Indonesia (TVRI) dan Radio Repulbik Indonesia (RRI). TVRI dan RRI saat ini mengalami kemunduran baik dari segi jumlah pemirsanya maupun dalam hal isi siarannya. Banyak masyarakat tidak lagi melihat keberadaan TVRI dan RRI sebagai salah satu lembaga penyiaran di Indonesia. Masyarakat saat ini lebih banyak mendengar atau melihat tayangan yang disiarkan oleh LPS.

Status kelembagaan LPP merupakan permasalahan utama yang dialami oleh LPP. Status Lembaga Penyiaran Publik belum dikenal dalam peraturan tentang keuangan negara. Oleh karena hal tersebut, kemudian hal ini juga yang menimbulkan LPP tidak mendapatkan nomenklatur tersendiri dalam Anggaran Pendapatan dan Belanja Negara (APBN). Status LPP sebagai badan hukum yang didirikan oleh negara juga kemudian menjadikan LPP sulit berkembang, hal ini dikarenakan tidak disebutkan secara tegas status badan hukumnya. Ketidakjelasan status kelembagaan ini menyebabkan berbagai permasalahan khususnya dalam bidang administrasi dan keuangan di tubuh LPP. Permasalahan di bidang administrasi dan keuangan ini kemudian menyebabkan program dan isi 
siaran LPP kurang diminati oleh masyarakat. UU Penyiaran mengatur Lembaga Penyiaran Swasta dalam Pasal 16 - 20. Pengaturan dalam Pasal 16 - 20 UU Penyiaran ini berkaitan dengan status badan hukum yang harus dimiliki oleh LPS, kepemilikan, sumber pembiayaan dan cakupan wilayah siaran. Masyarakat saat ini dapat melihat bahwa LPS dimiliki oleh beberapa orang saja. Bunga Kepemilikan LPS ini kemudian tidak lagi sesuai dengan pembatasan yang tertuang dalam UU Penyiaran yaitu keberagaman kepemilikan (diversity of ownership) dan keberagaman content (diversity of content). Pelanggaran terhadap prinsip ini yang kemudian menyebabkan banyak program acara yang monoton dan mengakibatkan hiburan yang tidak sehat bagi masyarakat.

Penyiaran memiliki peran yang sangat strategis dalam membangun demokrasi suatu bangsa, karena itu penyiaran juga merupakan kekuatan penyangga demokrasi yang harus didukung dan diberi ruang untuk kepentingan masyarakat. Media penyiaran pada umumnya dan seperti media televisi dan radio pada khususnya merupakan media massa yang dinamis serta atraktif dan merupakan media hasil kreativitas yang mendorong keingintahuan masyarakat untuk mengetahui lebih jauh proses terjadinya siaran dan kemajuan teknologi penyiaran serta regulasi dan kebijakan pemerintah yang mengaturnya. Bagi masyarakat Indonesia, media televisi maupun radio saat ini bukan saja sebagai media pendidikan, hiburan dan informasi, melainkan juga telah menjadi satu wahana pengikat antara masyarakat (pemirsa) dan penyelenggaraan siaran dalam suatu lingkaran industri. Oleh karena itu, sangat dibutuhkan informasi dari para praktisi dibidang penyiaran yang dapat memberikan jawaban seputar permasalahan penyelenggaraan penyiaran televisi maupun radio khususnya dan penyiaran pada umumnya (Djamal \& Fachruddin, 2017).

UU Penyiaran mencoba untuk menegakkan demokratisasi di bidang penyiaran. Prinsip dasar penyelenggaraan penyiaran berkaitan dengan prinsip-prinsip penjaminan dari negara agar aktivitas penyiaran yang dilakukan oleh lembaga penyiaran berdampak positif bagi publik. Dalam hal ini, publik harus memiliki akses yang memadai untuk dapat terlibat, memanfaatkan, mendapatkan perlindungan, serta mendapatkan keuntungan dari kegiatan penyiaran. Untuk mencapai keberhasilan dari prinsip ini, juga dibutuhkan prinsip lain, yang secara melekat (embedded) menyokongnya, yakni prinsip diversity of ownership (keberagaman kepemilikan) dan diversity of content (keberagaman isi) dari lembaga penyiaran (Bahreisy, 2017). Penyiaran diselenggarakan dengan tujuan untuk memperkokoh integrasi nasional, terbinanya watak dan jati diri bangsa yang beriman dan bertakwa, mencerdaskan kehidupan bangsa, memajukan kesejahteraan umum, dalam rangka membangun masyarakat yang mandiri, demokratis, adil dan sejahtera, serta menumbuhkan industri penyiaran Indonesia. Penyiaran diarahkan untuk menjunjung tinggi pelaksanaan Pancasila dan Undang-Undang Dasar Negara Republik Indonesia Tahun 1945, menjaga dan meningkatkan moralitas dan nilai-nilai agama serta jati diri bangsa, meningkatkan kualitas sumber daya manusia, menjaga dan mempererat persatuan dan kesatuan bangsa, meningkatkan kesadaran ketaatan hukum dan disiplin nasional, menyalurkan pendapat umum serta mendorong peran aktif masyarakat dalam pembangunan nasional dan daerah serta melestarikan lingkungan hidup, mencegah monopoli kepemilikan dan mendukung persaingan yang sehat di bidang penyiaran, mendorong peningkatan kemampuan perekonomian rakyat, mewujudkan pemerataan, dan memperkuat daya saing bangsa dalam era globalisasi, memberikan informasi yang benar, seimbang, dan bertanggung jawab dan memajukan kebudayaan nasional.

Bagi masyarakat Indonesia, media televisi maupun radio saat ini bukan saja sebagai media pendidikan, hiburan dan informasi, melainkan juga telah menjadi satu wahana pengikat antara masyarakat (pemirsa) dan penyelenggaraan siaran dalam suatu lingkaran industri. Oleh karena itu, sangat dibutuhkan informasi dari para praktisi dibidang penyiaran yang dapat memberikan jawaban seputar permasalahan penyelenggaraan penyiaran televisi maupun radio khususnya dan penyiaran pada umumnya (Djamal \& Fachruddin, 2017). Radio siaran mempunyai 4 fungsi antara lain fungsi penerangan, fungsi pendidikan, fungsi hiburan, sarana propaganda (Sampoerno et al., 2018). Sementara televisi sebagai salah satu lembaga komunikasi massa tidak berbeda dengan institusi bisnis lainnya yang bertujuan mencari keuntungan. Salah satu indikator utama bahwa sebuah produksi acara televisi dikatakan sukses adalah melalui jumlah rating yang diperolehnya. Berdasarkan survei, ratarata orang dewasa Amerika menghabiskan 9 jam 35 menit dalam sehari (60\%) untuk 
mengonsumsi isi media, dan media yang paling banyak dikonsumsi adalah televisi (Priyanti \& Erawati, 2017).

Dalam undang-undang penyiaran diatur tentang filosofi bagaimana sebenarnya arah pembangunan industri siaran di Indonesia, baik siaran televisi maupun radio. Pengaturan ini didasarkan pada beberapa hal yang utama yaitu pertama, penyiaran merupakan salah satu perwujudan bahwa negara menjamin hak setiap warga negara untuk bebas berekspresi dan mengeluarkan pendapat melalui media penyiaran. Kedua, industri siaran dalam kegiatannya menggunakan spektrum frekuensi radio (gelombang elektromagnetik) yang pada dasarnya milik publik yang harus digunakan untuk sebesar-besar kemakmuran rakyat. Ketiga, sistem penyiaran nasional di Indonesia harus menjamin terciptanya tatanan informasi yang adil dan merata,serta seimbang guna mewujudkan keadilan sosial bagi seluruh rakyat Indonesia. Keempat, lembaga penyiaran mempunyai peran yang harus dijalankan dengan kebebasan dan tanggung jawab dalam menjalankan fungsi sebagai media informasi, pendidikan, hiburan kontrol dan perekatsosial. Kelima, siaran yang dipancarkan dan disiarkan secara serentak akan mempunyai dampak yang besar dalam pembentukan pendapat, sikap dan perilaku khalayak, sehingga penyelenggara wajib bertanggung jawab dalam menjaga nilai moral, tata susila, budaya, kepribadian dan kesatuan bangsa yang sesuai dengan sila pertama dan kedua Pancasila .

Pada pandangan fungsionalis media, media merupakan lembaga dalam masyarakat dan memiliki fungsi tertentu bagi masyarakat (Fahrimal, 2018). Peranan dan fungsi media tersebut dapat dilihat pada efek dari media terhadap masyarakat (Hajar, 2019). Beberapa fungsi media bagi masyarakat yaitu: (1) fungsi informasi, terutama tentang peristiwa dan kondisi yang terjadi dalam masyarakat; (2) fungsi korelasi, media menjelaskan, menafsirkan, memberi komentar atas peristiwa; (3) fungsi keberlanjutan, menampilkan budaya dominan yang berlaku dalam masyarakat beserta perkembangannya; (4) fungsi hiburan, media memberikan kesenangan, pengalihan, dan sebagai sarana relaksasi; (5) fungsi mobilisasi, media dapat mengkampanyekan tujuan-tujuan sosial dan lainnya kepada masyarakat (Adhiarso et al., 2017). Hal yang paling penting adalah isi siaran wajib memberikan perlindungan dan pemberdayaan kepada khalayak khusus, yaitu anak-anak dan remaja. Perlindungan ini dijabarkan antara lain bahwa lembaga penyiaran harus menyiarkan mata acara pada waktu yang tepat, wajib mencantumkan dan/atau menyebutkan klasifikasi khalayak sesuai dengan isi siaran.

Kebutuhan akan informasi dengan menggunakan teknologi komunikasi harus dapat terjaga dengan baik, dengan kata lain diperlukan sistem pengamanan (security) karena secara tekhnis kebutuhan informasi dan sistem ini sendiri sangatlah rentan untuk tidak bekerja sebagaimana mestinya (malfunction), dapat diubah-ubah ataupun diterobos oleh pihak lain baik oleh orang maupun lembaga yang tidak bermaksud jahat maupun yang bermaksud jahat (Bahreisy, 2017). Prinsip dasar penyelenggaraan penyiaran akibat perkembangan teknologi dan informasi berkaitan erat dengan prinsip-prinsip penjaminan dari negara agar aktivitas penyiaran yang dilakukan oleh lembaga penyiaran berdampak positif bagi publik. Dalam hal ini, publik harus memiliki akses yang memadai untuk dapat terlibat, memanfaatkan, mendapatkan perlindungan, serta mendapatkan keuntungan dari kegiatan penyiaran. Undang-undang memberi hak, kewajiban dan tanggungjawab serta partisipasi masyarakat untuk mengembangkan penyiaran, seperti mengembangkan pribadi dan lingkungan sosialnya, mencari, memperoleh, memiliki dan menyimpan, mengolah dan menyampaikan informasi di lembaga penyiaran serta mengembangkan kegiatan literasi dan/atau pemantauan untuk mengawasi dan melindungi publik dari isi siaran yang merugikan masyarakat.

Undang-Undang RI Nomor 32 Tahun 2002 tentang penyiaran telah memberikan peluang untuk membuka dan mengembangkan lembaga penyiaran di Indonesia termasuk Kepulauan Riau, namun penyelenggaraan penyiaran tersebut diarahkan hanya berdasarkan Pancasila dan UndangUndang Dasar 1945 sebagaimana yang disebutkan pada Pasal 2 ayat (2). Pasal yang menerangkan dasar penyiaran ini sangat penting, sebab bisa jadi akan timbul dikemudian hari lembaga penyiaran yang tidak berdasarkan Pancasila. Dengan konsep kebebasan kepemilikan ini, menimbulkan persaingan usaha dalam bidang penyiaran, yang dianggap mampu untuk memajukan pertumbuhan 
lembaga penyiaran itu sendiri, inilah sistem ekonomi dalam bidang penyiaran yang menyerahkan persaingan usaha kepada pasar (kapitalisasi penyiaran).

Adapun dari segi fungsi penyelenggaraan penyiaran dicantumkan pada Pasal 4. Sementara untuk penyelenggara penyiaran terbagi dalam 4 (empat) kelompok sebagaimana tercantum dalam Pasal 13 ayat (2). Diantaranya, lembaga penyiaran publik (LPP), lembaga penyiaran swasta (LPS), lembaga penyiaran komunitas (LPK) dan lembaga penyiaran berlangganan (LPB) atau biasa disebut masyarakat dengan nama TV kabel. Rincian penjelasan masing-masing lembaga penyiaran tercantum dalam Pasal 14 menyebutkan tentang lembaga penyiaran publik, Pasal 16 menyebutkan tentang lembaga penyiaran swasta, selanjutnya lembaga penyiaran komunitas dijelaskan pada Pasal 21, selanjutnya lembaga penyiaran berlangganan dijelaskan pada Pasal 25, Pasal 26, Pasal 27 dan Pasal 28. Perkembangan lembaga penyiaran di Indonesia, tidak terlepas dari pengaruh regulasinya, sebab kegiatan penyelenggaraan penyiaran merupakan fakta hukum yang akan menimbulkan akibat-akibat hukum dan tidak hanya melibatkan antara masyarakat dengan lembaga penyiaran, tapi juga dengan pihak pemerintah sebagai pengontrol dan pengendali dalam kehidupan bernegara.

Di samping perkembangan teknologi komunikasi dan informasi telah membawa implikasi terhadap dunia penyiaran, termasuk penyiaran di Indonesia sehingga menjadikan penyiaran selain sebagai salah satu sarana berkomunikasi bagi masyarakat, dunia bisnis dan pemerintah, penyiaran juga telah menjadi suatu lembaga bisnis yang juga berperan dalam kegiatan ekonomi nasional, oleh karenanya diperlukan perlindungan terhadap dunia penyiaran di dalam perangkat peraturan perundangundangan terhadap tindak pidana yang berkaitan dengan penyiaran. Usaha untuk mengendalikan dan menanggulangi tindak pidana dibidang penyiaran adalah menentukan suatu perbuatan sebagai suatu tindak pidana (kriminalisasi). Kriminalisasi terhadap penyiaran di Indonesia baru dimulai pada tahun 1997 yaitu dengan terbitnya Undang-Undang Nomor 24 Tahun 1997 tentang Penyiaran. Undang-undang ini mengatur secara jelas tentang segala aspek yang terkait dengan penyiaran, termasuk pengaturan mengenai kepemilikan lembaga penyiaran. Berdasarkan ketentuan Undang-Undang Nomor 24 Tahun 1997 bahwa lembaga penyiaran di dalam negeri harus berorientasi pada kepentingan nasional Indonesia, sehingga modal pendirian lembaga penyiaran swasta harus modal nasional sehingga tidak dipengaruhi kepentingan lain dari luar (pihak asing).

Undang-Undang Nomor 24 Tahun 1997 tentang Penyiaran ini selanjutnya digantikan dengan UndangUndang Nomor 32 Tahun 2002 tentang Penyiaran. Masing-masing jenis lembaga penyiaran telah diatur tata cara penyelenggaraannya oleh Pemerintah. Saat ini, perkembangan lembaga penyiaran secara nasional sudah berkembang, hal ini ditandai dengan semakin bertambahnya lembaga penyiaran yang beridiri dengan dan/atau tanpa mendapatkan izin dari pihak Pemerintah. Perkembangan lembaga penyiaran di Indonesia pada dasarnya sudah mengalami kemajuan, namun perkembangan tersebut tentunya tidak lepas dari kendala yang menyebabkan pertumbuhannya tidak merata di berbagai kabupaten dan kota. Adapun beberapa kendala yang dihadapi oleh lembaga penyiaran.

Pertama, kesulitan mendapatkan investor. Masih minimnya minat pengusaha dalam negeri, terutama pengusaha tempatan yang berkeinginan untuk menanamkan modalnya dalam sektor penyiaran. Hal ini terkait, lambatnya proses mendapatkan izin penyelenggaraan penyiaran (IPP). Kendala ini menjadi salah satu alasan kenapa investasi di sektor penyiaran, terutama dari pemodal nasional masih minim dan terkesan wait and see. Sementara investor tempatan masih belum memahami benar tentang kondisi, tantangan, ancaman dan peluang dalam berusaha dalam sektor penyiaran. Riyanto, (2016) menyebutkan jika biasanya, lembaga penyiaran yang masuk kedalam objek rating AC Nielsen dengan jumlah pendengar atau penonton banyak/tinggi akan memiliki daya tarik bagi investor. Sebab para investor mengetahui bahwa roh lembaga penyiaran itu terletak pada iklan niaga, sementara pemasukan dari iklan niaga akan besar apabila rating tinggi. Kedua, jumlah penduduk rendah. Investor dalam menanamkan modalnya pasti memiliki orientasi untung/laba. Sementara laba yang besar hanya didapatkan dari iklan yang banyak, Sementara iklan itu sendiri ditentukan oleh rating dari jumlah penonton/pendengar. Jika penonton/pendengarnya sedikit maka dengan sendirinya keuntungan juga akan tergolong rendah/sedikit. 
Ketiga, proses perizinan panjang dan lama. Lambatnya proses mendapatkan izin penyelenggaraan penyiaran, dan memang ini tidak hanya terjadi di beberapa daerah namun hampir merata diseluruh wilayah Indonesia dan bahkan ada salah satu lembaga penyiaran radio yang memakan waktu 5 (lima) tahun untuk mendapatkan Izin Penyelenggaraan Penyiaran (IPP) tetap. Setelah pemohon menerima izin prinsip, maka pemohon wajib untuk membenahi semua kebutuhan produksi penyiarannya, mulai dari mendirikan tower, menggelar jaringan, melakukan uji coba siaran dll selama satu tahun. Setelah satu tahun, lembaga penyiara wajib untuk mengirimkan surat kepada Kementrian komunikasi dan informatika yang menerangkan bahwa lembaga penyiaran siap untuk dilakukan evaluasi Uji Coba Siaran (UCS), setelah Menteri Komunikasi dan Informatika melakukan evaluasi uji coba siaran maka Menkominfo selanjutnya akan mengeluarkan Izin Siaran Radio (ISR). Persoalannya muncul ketika Menkominfo mengeluarkan ISR pemohon bisa memakawan waktu 4 (empat) sampai 5 (tahun). Keempat, biaya investasi mahal. Mahalnya biaya yang harus dikeluarkan oleh lembaga penyiaran, terutama lembaga penyiaran berlangganan (televisi kabel). Seperti yang dijelaskan oleh Hadiyat (2016), televisi kabel yang tidak mengambil program-program siaran melalui konten provider, maka biasanya dilakukan melalui satelit, sementara cara seperti inipun tergolong mahal, televisi kabel tersebut harus menyiapkan hak siar atau hak labuh (landing right) yang biasanya bisa mencapai belasan juta. Permasalahan-permasalahan yang dihadapi oleh UU penyiaran merupakan permasalahan krusial bagi lembaga penyiaran, pemerintah maupun KPI. KPI dalam menjalankan fungsi, tugas, hak dan kewajibannya harus diatur dalam peraturan perundangundangan. adapun aturan tersebut harus dengan jelas memaparkan apa saja yang menjadi hak dan kewajiban KPI. Selain hal tersebut, perlu ada ketegasan subjek yang bertugas untuk memberi sanksi administratif dalam UU Penyiaran. Oleh karena itu, fungsi KPI dalam kegiatan penyiaran perlu diperluas.

\section{Simpulan}

Media penyiaran menjalankan tugas dan fungsinya sebagaimana yang telah diatur oleh UU Penyiaran, karena itu semua media penyiaran termasuk praktisinya harus taat dengan hukum dan etika penyiaran. Peran dan fungsi media penyiaran Radio dan Televisi saat ini semakin besar seiring dengan perkembangan zaman khususnya perkembangan masyarakat dan negara. Pemerintahan yang bersih (clean government), negara demokratis yang sesungguhnya serta penegakan nilai-nilai keadilan di masyarakat tidak akan terwujud apabila peran dan fungsi penyiaran tidak dimaksimalkan.

\section{Daftar Pustaka}

Adhiarso, D. S., Utari, P., \& Slamet, Y. (2017). Pemberitaan Hoax di Media Online Ditinjau dari Konstruksi Berita dan Respon Netizen. Jurnal Ilmu Komunikasi, 15(3), 215-225. http://jurnal.upnyk.ac.id/index.php/komunikasi/article/download/2173/1911.

Ahmad Budiman. (2016). Model Pengelolaan Digitalisasi Penyiaran di Indonesia. Jurnal Politica Dinamika Masalah Politik Dalam Negeri Dan Hubungan Internasional, 6(2). https://doi.org/10.22212/jp.v6i2.307.

Bahreisy, B. (2017). Pertanggungjawaban Pidana Bagi Pelaku Penggunaan Frekuensi Radio Tanpa Izin Berdasarkan Undang-undang Tentang Telekomunikasi (Criminal of Perpetrators of Use of Illegal Radio Frequencies Under the Act of Telecommunication). Jurnal Penelitian Hukum De Jure, 16(3), 265-276. https://doi.org/10.46576/wdw.v0i49.157.

Denico Doly. (2021). Peran Negara Dalam Pengelolaan Spektrum Frekuensi Radio Dalam Perspektif Hukum. Kajian, 23(4), 267-283. https://doi.org/10.22212/kajian.v23i4.2115.

Djamal, H., \& Fachruddin, A. (2017). Dasar-dasar Penyiaran: Sejarah, Organisasi, Operasional, dan Regulasi (edisi 2). Prenada Media.

Fahrimal, Y. (2018). Netiquette: Etika Jejaring Sosial Generasi Milenial Dalam Media Sosial. Jurnal Penelitian Pers Dan Komunikasi Pembangunan, 11(1), 69-78. https://doi.org/10.46426/jp2kp.v22i1.82. 
Gultom, A. D. (2015). Kajian implementasi radio siaran digital di Indonesia. Buletin Pos Dan Telekomunikasi, 13(2), 133-150. https://doi.org/10.17933/bpostel.2015.130203.

Hajar, I. (2019). Youtube sebagai Sarana Komunikasi Dakwah di Kota Makassar (Analisis Sosial Media). Jurnal Al-Khitabah, 4(2), 79-94. http://journal.uin-alauddin.ac.id/index.php/AlKhitabah/article/download/6951/5719.

Kridasaksana, D., Junaidi, M., \& Aryaputra, M. I. (2017). Tujuan Negara Dalam Mengatur Frekuensi Radio Komunitas Ditinjau Dari Undang-Undang Nomor 32 Tahun 2002 Tentang Penyiaran (Studi Kasus Di Wilayah Semarang). Jurnal Dinamika Sosial Budaya, 17(2), 242-257. https://156.67.218.228/index.php/jdsb/article/view/489.

Priyanti, E., \& Erawati, W. (2017). Perancangan Animasi Interaktif Belajar Mengenal Planet Dalam Sistem Tata Surya. Konferensi Nasional IImu Sosial \& Teknologi (KNiST), 1(1), 401-405.

Sampoerno, S., Herwandito, S., \& Sari, D. K. (2018). Pergeseran Peran dan Fungsi Radio Suara Surabaya dari Radio Informasi Menjadi Radio Pengaduan. Jurnal Riset Komunikasi, 1(1), 1-13. https://doi.org/10.24329/jurkom.v1i1.6.

Stirman, P. G. (2016). Kajian Hukum Terhadap Pelaksanaan Siaran Televisi Menurut Undang-undang No. 32 Tahun 2002 Tentang Penyiaran. Lex Privatum, 4(4). https://ejournal.unsrat.ac.id/index.php/lexprivatum/article/view/12029.

Yuniarti, D., \& Kusumawardani, Q. D. (2018). Public Acceptance Strategies for Digital Terrestrial Television (DTT) in the Border Areas. 2018. International Conference on ICT for Rural Development (IC-ICTRuDev), 148-154. https://doi.org/10.1109/ICICTR.2018.8706876. 